\title{
LESZEK KARSKI
}

Instytut Ekologii i Bioetyki, UKSW, Warszawa

\section{Eksperyment medyczny przeprowadzany na organizmie ludzkim - aspekty prawa międzynarodowego, europejskiego i krajowego}

Słowa kluczowe: eksperyment medyczny, badania medyczne na ludziach, międzynarodowe prawo, europejskie prawo, krajowe prawo

Key words: medical experimentation, medical research on human subjects, international law, European law, domestic law

\section{SUMMARY}

Medical experiment conducted on human subject - aspects of international, European and national laws

The article is designed to provide readers with a legal context of medical experimentation. Medical research involving humans needs careful regulation. Although international law, European law, and domestic law are usually described as separate sources of law, they are increasingly interdependent. Their interaction produces a layering effect of laws that address medical experimentation. The paper begins with an overview of content of soft international law. In the next section the author addresses the issue of hard law, i.e. the Geneva Conventions, provisions of the International Covenant on Civil and Political Rights and International Covenant on Economic, Social and Cultural Rights. The Convention for the Protection of Human Rights and Dignity of the Human Being with regard to the Application of Biology and Medicine is the subject of analysis in the third part of the paper. The next section 
discusses selected issues related to regulations of European Union law. At the national level, the Polish Constitution provides for a medical research principium. In order to provide deeper insight, the next part of analysis is based on domestic criminal law. The final section discusses the role of the physician in medical research in light of the norm included in the 1996 Act on the professions of the physician and dentist.

\section{Wprowadzenie}

Problematyka eksperymentu medycznego przeprowadzanego na człowieku wzbudza mieszane uczucia i wiąże się z szeregiem odmiennych stanowisk. Z jednej strony zdajemy sobie sprawę, iż podwyższanie jakości życia wymaga prowadzenia różnorodnych naukowych badań medycznych. Z drugiej strony pojawiają się opory etyczne (Łuków 2011: $6 \mathrm{i}$.). W jeszcze innym świetle eksperyment medyczny jest widziany, kiedy przechodzi się do aspektu ekonomicznego. Ten konglomerat różnych podjeść i ambiwalentnych uczuć jest przekładany na system normatywny. Podstawowa kwestia - pogodzenie rozwoju i zaspokojenia potrzeb społeczeństwa oraz indywidualnych potrzeb naukowych i gospodarczych $z$ indywidualnymi prawami człowieka, który staje się przedmiotem badań (Woltjen 1986: 507), jest motorem rozwoju globalnego prawa dotyczącego eksperymentu medycznego.

\section{Poziom ogólnoświatowy - prawo miękkie}

Refleksja nad eksperymentem medycznym wiąże się $\mathrm{z}$ potrzebą umiejscowienia analizowanego zagadnienia wśród badań naukowych. Oznacza, to, iż punktem wyjścia jest odniesienie się do zakresu wolności, którą dysponuje badacz. Zasadniczo panuje generalna wolność naukowa (web-01; Baker 1978: 382 i n). Nauka jako fundamentalny element kultury człowieka wiąże się z rozwojem zarówno jednostki, jak i społeczeństwa. Przy innej płaszczyźnie, nauka to klucz do rozwoju społecznego i gospodarczego. Dlatego nie może dziwić, iż w Powszech- 
nej Deklaracji Praw Człowieka z 1948 r. (web-02) wśród praw wyróżniono prawo do badań naukowych. W myśl ust. 1 art. 27 wspomnianej deklaracji, każdy człowiek ma prawo do swobodnego uczestniczenia w życiu kulturalnym społeczeństwa, do korzystania ze sztuki, do udziału w postępie naukowym i korzystania z jego dobrodziejstw.

Jednak nauka coraz bardziej i szybciej wnika w obszary, które są $z$ różnych powodów otoczone szczególną ochroną. Chodzi tu zarówno o prawa innych jednostek, jak i o dobro wspólne. Wiąże się to z potrzebą wyznaczania pewnych granic w celu ochrony człowieczeństwa (President's Council on Bioethics 2002: 168). Prawo do badań naukowych z ius infinitum w praktyce zaczyna przeradzać się w prawo ograniczone. Konieczność limitowania swobody w pewnych obszarach jest oparta na personalistycznym podejściu do człowieka. Tam gdzie pojawia się możliwość naruszenia godności człowieka i wypływających z niej fundamentalnych praw, tam pojawia się granica dla swobody badawczej. Granica ta może być pozostawiona moralności badacza - i taka jest zasada. Wyjątkiem od niej są kwestie, w przypadku których interes publiczny wymaga ingerencji państwa i to zarówno przez wzgląd na dobro wspólne, jak i dobro poszczególnych jednostek. Wkracza wtedy regulacja prawna. Eksperyment medyczny stanowi ewidentny przykład takiego wyjątku. Treścią tego odstępstwa jest ograniczenie wolności naukowej przez prawodawcę. Jest to $\mathrm{w}$ pełni zgodne $\mathrm{z}$ postanowieniami Powszechnej Deklaracji Praw Człowieka. Zgodnie z art. 29 wspomnianego aktu prawa miękkiego w korzystaniu ze swych praw i wolności każdy człowiek podlega jedynie takim ograniczeniom, które są ustalone przez prawo wyłącznie w celu zapewnienia odpowiedniego uznania i poszanowania praw i wolności innych i w celu uczynienia zadość słusznym wymogom moralności, porządku publicznego i powszechnego dobrobytu demokratycznego społeczeństwa.

W Powszechnej Deklaracji Praw Człowieka nie nawiązano bezpośrednio do kwestii eksperymentu medycznego i prawidłowych warunków jego przeprowadzania. Warto zarazem podkreślić, iż z ogólnych postanowień można wyinterpretować powiązanie $\mathrm{z}$ przedmiotem 
analizy. Można to odnieść do dwóch aspektów. Pierwszy dotyczy potrzeby przeprowadzania eksperymentów medycznych, przez wzgląd na postęp społeczny i poprawę warunków życia w większej wolności (preambuła). Do omówionych powyżej kwestii dotyczących prawa do prowadzenia badań naukowych, dodać również wypada fundament tej aktywności. Wolność badawcza ma na celu jak najpełniejsze umożliwienie realizacji prawa każdego człowiek do stopy życiowej, która zapewnia zdrowie i dobrobyt jego i jego rodziny, włączając w to wyżywienie, odzież, mieszkanie, opiekę medyczną i konieczne świadczenia socjalne, oraz prawo do ubezpieczenia na wypadek bezrobocia, choroby, niezdolności do pracy, wdowieństwa, starości lub utraty środków do życia w inny sposób od niego niezależny - jak można to odnieść do treści art. 25. Drugi dotyczy zakazu przeprowadzania badań medycznych, które by godziły w prawa człowieka (przede wszystkim art. 1, art. 3 i art. 5). A zatem wyznaczenie granic dla wolności badawczej będzie się sprowadzało do sprawdzenia, czy nie dochodzi do zderzenia z deklarowanymi podstawowymi prawami człowieka. Takie zderzenie będzie zasadniczo limitowało swobodę badawczą. Ograniczenia tego typu mogą być wprowadzane poprzez prawodawców krajowych, co zostało już przytoczone.

Znaczenie Powszechnej Deklaracji Praw Człowieka jest w omawianym obszarze niezwykle doniosłe, pomimo tego, iż nie jest formalnie obowiązującym prawem. W literaturze przedmiotu zwracano uwagę na to, iż przynajmniej część treści analizowanej Deklaracji przeszła proces przekształcenia w wiążące prawo zwyczajowe (Czapliński, Wyrozumska 2004: 432; Kramska 2011: 58).

\section{Poziom ogólnoświatowy - prawo twarde}

W prawie twardym kwestia eksperymentu medycznego została uregulowana poprzez konwencje dotyczące prawa konfliktów zbrojnych oraz prawa człowieka. Jest to związane z doświadczeniami wojennymi. Okrucieństwo niektórych jednostek podczas II wojny światowej (Lar- 
sen 1976: 163; web-03) dało asumpt do rozważenia na jakim poziomie powinno się zakazać eksperymentów „pseudomedycznych”. Wykorzystywanie jeńców i więźniów do przeprowadzania eksperymentów, których skutkiem miało być poszerzenie wiedzy medycznej, wiązało się z pogwałceniem podstawowych praw człowieka. W związku z tym zagadnienie eksperymentu medycznego było wiązane przede wszystkim z kwestią ochrony przed nadużyciami i łamaniem praw człowieka. Rozważając regulacje prawnomiędzynarodowe, przede wszystkim należy wymienić reżim Konwencji Genewskich (A; web-04) oraz Międzynarodowy Pakt Praw Obywatelskich i Politycznych otwarty do podpisu w Nowym Jorku dnia 19 grudnia 1966 r. (C) Zarówno w Konwencjach Genewskich, jak i w Pakcie, prawodawca międzynarodowy poprzez treść bezpośrednio wyrażoną, skupia się na aspekcie generalnego zakazu przeprowadzania eksperymentu medycznego. Przykładowo w Konwencji Genewska o ochronie osób cywilnych podczas wojny (IV Konwencja Genewska) aż dwa artykuły odnoszą się do eksperymentu medycznego (B). Zgodnie z art. 32, strony Konwencji wyraźnie uznały, iż zabronione jest stosowanie wszelkich środków mogących powodować cierpienia fizyczne lub wyniszczenie osób podlegających ochronie, które znajdują się w ich władzy. Zakaz ten obejmuje nie tylko zabójstwa, torturowanie, kary cielesne, okaleczenia i eksperymenty medyczne lub naukowe, które nie są konieczne dla leczenia osoby podlegającej ochronie, ale również wszelkie inne akty brutalności ze strony funkcjonariuszy cywilnych lub wojskowych. Z kolei w artykule 147 Konwencji uznano, iż za ciężkie naruszenie w rozumieniu artykułu 146 uważa się, między innymi, przeprowadzenie eksperymentu biologicznego na szkodę osób chronionych Konwencją. Wiąże się z tym szereg konsekwencji dla prawodawców krajowych oraz ścigania przez państwa. Na podstawie art. 146 Konwencji, Strony zobowiązały się do wydania niezbędnych przepisów ustawodawczych w celu ustalenia odpowiednich sankcji karnych w stosunku do osób, które popełniły lub wydały rozkaz popełnienia jakiegokolwiek z ciężkich naruszeń niniejszej Konwencji. Każda Strona obowiązana będzie poszukiwać osoby podejrzane o popełnienie 
lub o wydanie rozkazu popełnienia jakiegokolwiek z tych ciężkich naruszeń i powinna ścigać je przed swoimi własnymi sądami niezależnie od obywatelstwa. Będzie ona również mogła, jeżeli woli, wydać te osoby na warunkach przewidzianych przez jej własne ustawodawstwo do osądzenia innej zainteresowanej w ściganiu Stronie, jeżeli ta Strona posiada dostateczne dowody obciążające przeciwko powyższym osobom.

Kwestia eksperymentu medycznego dosyć szybko pojawiła się $\mathrm{w}$ dyskusjach międzynarodowych $\mathrm{w}$ aspekcie zagwarantowania praw człowieka również w czasie pokoju.

Znalazło to odzwierciedlenie w normie przewidzianej w art. 7 wspomnianego już Międzynarodowego Paktu Praw Obywatelskich i Politycznych. Prawodawca międzynarodowy ujął to w następujący sposób: „Nikt nie będzie poddawany torturom lub okrutnemu, nieludzkiemu albo poniżającemu traktowaniu lub karaniu. W szczególności nikt nie będzie poddawany, bez swej zgody swobodnie wyrażonej, eksperymentom medycznym lub naukowym.. Umieszczenie zakazu przeprowadzania eksperymentu w pakcie odnoszącym się do pierwszej generacji praw człowieka, należy uznać za podkreślenie jego wagi (Boven 1982: 43). Generalny zakaz przeprowadzenia eksperymentu może być uchylony w przypadku swobodnie wyrażonej zgody osoby, która ma być poddana eksperymentowi medycznemu. Konstrukcja wykreowana przez prawodawcę międzynarodowego $\mathrm{w}$ art. 7 Paktu stanowi źródło i fundament dla regulacji na niższych poziomach stanowienia prawa. Jest to widoczne zarówno na poziomie europejskim oraz krajowym. Jednak zakaz nadal jest łamany i to niekoniecznie w państwach rozwijających się (Herling 2006: 616).

W Międzynarodowym Pakcie Praw Gospodarczych, Społecznych i Kulturalnych również odniesiono się pośrednio do eksperymentu medycznego. Zgodnie z artykułem 12: „Państwa Strony niniejszego Paktu uznają prawo każdego do korzystania $\mathrm{z}$ najwyższego osiągalnego poziomu ochrony zdrowia fizycznego i psychicznego. 
2. Kroki, jakie Państwa Strony niniejszego Paktu powinny podjąć dla osiągnięcia pełnego wykonania tego prawa, będą obejmowały środki konieczne do:

a) zapewnienia zmniejszenia wskaźnika martwych urodzeń i śmiertelności niemowląt oraz do zapewnienia zdrowego rozwoju dziecka;

b) poprawy higieny środowiska i higieny przemysłowej we wszystkich aspektach;

c) zapobiegania chorobom epidemicznym, endemicznym, zawodowym i innym oraz ich leczenia i zwalczania;

d) stworzenia warunków, które zapewniłyby wszystkim pomoc i opiekę lekarską na wypadek choroby."

Treść przytoczonego fragmentu Paktu uzasadnia tezę, iż prawo każdego do korzystania z najwyższego osiągalnego poziomu ochrony zdrowia fizycznego i psychicznego, będzie realizowane między innymi dzięki dokonywaniu eksperymentów medycznych.

\section{Poziom europejski}

Jednym z najistotniejszych wysiłków na rzecz ujednolicenia standardów prawnych odnośnie eksperymentu medycznego jest Konwencja o Ochronie Praw Człowieka i Godności Istoty Ludzkiej w Kontekście zastosowań Biologii i Medycyny: Konwencja o Prawach Człowieka i Biomedycynie (web-05). Zadaniem aktu jest „zaszczepienie jej ducha” oraz nadawanie kierunku legislacyjnych rozwiązań na poziomie krajowym (Łuków 2007: 7). Adresatami Konwencji są państwa strony. Postanowienia analizowanego aktu, które odnoszą się do badań naukowych, mają charakter ogólny (Safjan 2000: 5-18). Szczegółowe rozwiązania prawne są pozostawione Protokołowi oraz prawodawcom krajowym. Minimalne wymagania, które odnoszą się do eksperymentu medycznego, przede wszystkim są związane $z$ zapewnieniem praw osoby, na której organizmie przeprowadzany jest eksperyment medyczny.

Przeprowadzając studia, warto zwrócić uwagę, iż w treści Konwencji nie pojawia się termin eksperyment medyczny. Powód odstąpienia od 
pojęcia występującego zarówno w języku prawnym, jak i prawniczym państw, których przedstawiciele brali udział w pracach nad projektem (Wachter 1997: 13), jest zaskakujący. Ponadto w ten sposób nastąpiło odejście od siatki terminologicznej przyjętej na poziomie ogólnoświatowym. Zamiast tego terminu użyto pojęcia badania naukowe.

Podstawą przepisów dotyczących badań naukowych są pierwsze cztery artykuły Konwencji.

Nadrzędnym przedmiotem ochrony jest godność i tożsamość istoty ludzkiej, co zostało podkreślone w art. 1. Państwa strony powinny gwarantować każdej osobie, bez dyskryminacji, poszanowanie dla jej integralności oraz innych podstawowych praw i wolności wobec zastosowań biologii i medycyny. Aby ochrona miała realny kształt państwa strony powinny podjąć w prawie wewnętrznym konieczne środki w celu zapewnienia skuteczności przepisów niniejszej Konwencji. Kolejna jednostka redakcyjna zawiera zasadę prymatu jednostki indywidualnej nad wyłącznym interesem społeczeństwa lub nauki. Poprzez art. 4 prawodawca europejski uznał, iż jakakolwiek interwencja w dziedzinie zdrowia, w tym badania naukowe, musi być przeprowadzona przy poszanowaniu norm i obowiązków wynikających z zasad postępowania zawodowego, jak również reguł postępowania, które mają zastosowanie w konkretnym przypadku. Jedynie art. 3 nie odnosi się bezpośrednio do eksperymentu medycznego. „Uwzględniając potrzeby zdrowotne oraz dostępne środki, strony podejmą w ramach swoich właściwości, stosowne działania w celu zapewnienia sprawiedliwego dostępu do opieki zdrowotnej o właściwej jakości.” Zarazem warto zauważyć, iż odniesienie się do jakości może być wiązane z wykorzystaniem eksperymentu medycznego. Tak szerokie nawiązywanie do badań naukowych w rozdziale I zatytułowanym Postanowienia ogólne, ukazuje ich znaczenie dla przedmiotu regulacji. Badania naukowe zajmują centralną pozycję.

Rozdział V Konwencji został poświecony badaniom naukowym. Prawodawca europejski, w ślad za postanowieniami Powszechnej Deklaracji Praw Człowieka uznał w art. 15, iż badania naukowe w dzie- 
dzinie biologii i medycyny prowadzone są w sposób swobodny. Jednak ochrona istoty ludzkiej stanowi istotny wyłom od tej generalnej zasady. Badania przeprowadzana na ludziach stanowią są poddane daleko idącej opiece i ingerencji. Na pierwsze miejsce wysunięto kwestie praw człowieka, które muszą być zagwarantowane dla osób poddawanych badaniom. Przeprowadzanie badań naukowych na ludziach jest dopuszczalne, o ile zostaną spełnione wszystkie następujące warunki:

- brak metody o porównywalnej skuteczności, alternatywnej do badań na ludziach,

- ryzyko podejmowane przez osobę poddaną badaniom jest proporcjonalne do potencjalnych korzyści wynikających z tych badań,

- projekt badań został zatwierdzony przez właściwą instytucję w wyniku niezależnej oceny jego wartości naukowej, w tym wagi celu badań i po przeprowadzeniu wszechstronnej oceny co do jego dopuszczalności pod względem etycznym,

- osoba poddawana badaniom jest informowana o swoich prawach oraz o ochronie gwarantowanej jej w przepisach prawa,

- wymagana zgoda, o której mowa w artykule 5, powinna być wyrażona w sposób wyraźny i dotyczyć konkretnego badania oraz powinna być udokumentowana. W każdej chwili można swobodnie zgodę wycofać.

Prawodawca zaznaczył, iż możliwość przeprowadzenia badań na ludziach wiąże się ze spełnieniem wszystkich warunków łącznie. Brak chociażby jednej z przesłanek powoduje, iż przeprowadzana czynność jest niezgodna z treścią Konwencji. Obowiązek udowodnienia spełnienia warunków obciąża podmioty, które prowadzą badania naukowe.

Pierwszy z warunków dotyczy sytuacji, w której nie ma alternatywnego rozwiązania w stosunku do badania na ludziach. Zatem można uznać, iż badanie na ludziach jest ostatecznością. Kolejną kwestią jest odniesienie się do kwestii ryzyka, które obarcza osobę poddaną badaniom i wyważenia go $\mathrm{w}$ aspekcie potencjalnych korzyści, którym ma służyć eksperyment medyczny. Wydaje się, iż niezbędnym procesem w tym względzie jest zarządzanie ryzykiem (Wójcik 2011: 47 i n.). Rów- 
nież niezbędnym elementem jest zatwierdzenie projektu badań przez wyznaczoną przez państwo instytucję. Instytucja powinna kierować się kryteriami: wartości naukowej, w tym wagi celu badań oraz względami etycznymi. Wydaje się, iż brak wystąpienia wartości naukowej lub względów etycznych zobowiązuje do odrzucenia projektu. Ocena w tym względzie powinna być wszechstronna w aspekcie dopuszczalności pod względem etycznym. Następnym conditio sine qua non jest obowiązek informowania osoby poddawanej badaniom o prawach oraz o ochronie gwarantowanej w przepisach prawa (Drozdowska, Wojtal 2010: 74-80). Najistotniejszym warunkiem z punktu widzenia praw człowieka jest swobodna i świadoma zgoda osoby, poddanej interwencji badawczo-medycznej. Powinna być ona wyrażona w sposób wyraźny i dotyczyć konkretnego badania oraz powinna być udokumentowana. Co niezwykle istotne zgoda w każdej chwili może być swobodnie wycofana przez osobę, na której jest przeprowadzany eksperyment medyczny.

W art. 17 unormowano kwestię ochrony osób niezdolnych do wyrażenia zgody. Badania naukowe na osobie nie posiadającej zdolności do wyrażenia na nie swobodnej i świadomej zgody mogą być przeprowadzone tylko przy spełnieniu wszystkich pozostałych warunków przewidzianych dla eksperymentu przeprowadzanego na osobie mającej zdolność do swobodnego i świadomego wyrażenia zgody. Ponadto dodano kolejne warunki, które również muszą być spełnione:

- oczekiwane wyniki badań są w stanie zapewnić rzeczywistą i bezpośrednią korzyść dla zdrowia osoby, na której organizmie ma być przeprowadzany eksperyment,

- badania o porównywalnej skuteczności nie mogą być przeprowadzone na osobach posiadających zdolność do wyrażenia zgody,

- wymagana zgoda, o której mowa w artykule 6 Konwencji, została wyrażona na piśmie i dotyczy konkretnego badania,

- osoba poddana badaniom nie sprzeciwia się ich przeprowadzeniu.

Prawodawca europejski odniósł się również do badań na embrionach in vitro. Poprzez art. 18 uznano, iż jeżeli prawo krajowe zezwala na przeprowadzanie badań na embrionach in vitro, powinno ono za- 
pewnić odpowiednią ochronę tym embrionom. Ponadto kategorycznie stwierdzono, iż tworzenie embrionów ludzkich dla celów naukowych jest zabronione. Nie wnikając w kwestie dyskusyjne, warto byłoby się zastanowić, czy poprzez taką regulację prawodawca europejski nie zapewnia embrionom ludzkim statusu istoty ludzkiej. Wskazywałaby na to treść art. $18 \mathrm{w}$ związku z postanowieniem art. 15.

\section{Poziom unijny}

$\mathrm{Na}$ poziomie regionalnym istotne znacznie mają również unijne rozwiązania. Szczególną uwagę należy skupić na kwestii badań klinicznych. Tematyce tej poświecono osobny akt rangi dyrektywy. Kwestia badań klinicznych została uregulowana w dyrektywie 2001/20/WE Parlamentu Europejskiego i Rady z dnia 4 kwietnia 2001 r. w sprawie zbliżania przepisów ustawowych, wykonawczych i administracyjnych Państw Członkowskich, odnoszących się do wdrożenia zasady dobrej praktyki klinicznej w prowadzeniu badań klinicznych produktów leczniczych, przeznaczonych do stosowania przez człowieka (G). Podstawą wydania dyrektywy było zbliżenie prawodawstwa państw członkowskich w aspekcie wewnętrznego rynku (Schott 2005: 60-78).

Zarazem jednak $\mathrm{w}$ preambule podkreślono, iż przyjętą podstawą przeprowadzania badań klinicznych $\mathrm{z}$ udziałem ludzi jest ochrona praw człowieka i godności istoty ludzkiej przy stosowaniu biologii i medycyny. Ochronę uczestników badań klinicznych zapewniają: ocena ryzyka, dokonywana przed rozpoczęciem jakiegokolwiek badania klinicznego na podstawie wyników badań toksykologicznych, wstępna ocena badania dokonywana przez komitety etyczne i właściwe organy państw członkowskich oraz przepisy o ochronie danych osobowych.

Akt zawiera przepisy szczególne, dotyczące prowadzenia badań klinicznych, w tym badań wieloośrodkowych, z udziałem ludzi. Centralnym przedmiotem zainteresowania prawodawcy unijnego jest wprowadzanie w życie dobrej praktyki klinicznej. Zgodnie z ust. 2 art. 1 dobra praktyka kliniczna stanowi zespół uznawanych przez społeczność 
międzynarodową wymagań dotyczących etyki i jakości badań naukowych, które muszą być przestrzegane przy planowaniu, przeprowadzaniu, rejestrowaniu i publikacji badań klinicznych, których uczestnikami są ludzie (Kondrat 2009: 274). Zgodność z dobrą praktyką kliniczną stanowi gwarancję ochrony praw, bezpieczeństwa i dobra uczestników badań klinicznych, a także wiarygodności ich wyników. Wszystkie badania kliniczne, w tym badania dotyczące dostępności biologicznej i równoważności biologicznej, są planowane, prowadzone i publikowane zgodnie z zasadami dobrej praktyki klinicznej. $\mathrm{Z}$ tego też powodu tak istotne znaczenie posiada regulacja zamieszczona $\mathrm{w}$ dyrektywie 2005/28/WE z dnia 8 kwietnia 2005 r. ustalająca zasady oraz szczególowe wytyczne dobrej praktyki klinicznej w odniesieniu do badanych produktów leczniczych przeznaczonych do stosowania u ludzi, a także wymogi zatwierdzania produkcji oraz przywozu takich produktów $(\mathrm{H})$.

Dyrektywa 2001/20/WE nie dotyczy badań nieinterwencyjnych. Fundamentalną zasadą unijnego prawa jest ochrona uczestników badań klinicznych. W art. 4. dyrektywy 2001/20/WE podkreślono zasadę wyższego standardu. Postanowienia dyrektywy stosuje się bez uszczerbku dla przepisów prawa krajowego, dotyczących ochrony uczestników badań klinicznych, które mogą być bardziej wymagające i wyczerpujące.

Prawodawca unijny podkreślił, iż badanie kliniczne można prowadzić tylko pod następującymi warunkami:

a) porównano możliwe do przewidzenia ryzyko i niedogodności z przewidywanymi korzyściami dla poszczególnych uczestników badania oraz dla innych, obecnych lub przyszłych pacjentów. Badanie kliniczne można rozpocząć tylko wtedy, gdy komitet etyki i/lub właściwy organ uzna, że przewidywane korzyści terapeutyczne i dotyczące zdrowia publicznego uzasadniają ryzyko; badanie można kontynuować tylko wtedy, gdy zgodność z tym wymaganiem jest nieustannie monitorowana;

b) uczestnik badania, a w przypadku, gdy osoba ta nie jest zdolna do wyrażenia świadomej zgody, jego przedstawiciel ustawowy miał 
możność, podczas przeprowadzonej przed badaniem rozmowy z prowadzącym badanie lub członkiem zespołu prowadzącego badanie, zapoznać się z celami, ryzykiem i niedogodnościami związanymi $\mathrm{z}$ tym badaniem klinicznym, warunkami w jakich ma ono zostać przeprowadzone, a także został poinformowany o przysługującym mu prawie do wycofania się z badania klinicznego w dowolnej chwili;

c) przestrzegane jest prawo uczestnika do fizycznej i psychicznej nietykalności jego osoby, do intymności oraz do ochrony jego danych osobowych zgodnie z dyrektywą 95/46/WE;

d) uczestnik badania, a w przypadku, gdy osoba ta nie jest zdolna do wyrażenia świadomej zgody, jego przedstawiciel ustawowy, wyraził pisemną zgodę po otrzymaniu informacji na temat charakteru, znaczenia, skutków i ryzyka związanego z tym badaniem klinicznym; jeżeli dana osoba nie jest w stanie pisać, może ona w wyjątkowych przypadkach, przewidzianych w prawie krajowym, wyrazić zgodę ustnie w obecności co najmniej jednego świadka;

e) uczestnik badania może w każdej chwili bez szkody dla siebie wycofać się z badania klinicznego poprzez odwołanie swojej świadomej zgody;

f) istnieją przepisy dotyczące ubezpieczenia lub odszkodowania od odpowiedzialności prowadzącego badanie i sponsora (Walter 2004: 291-296).

Proces dostosowania prawa polskiego do wymagań unijnych w analizowanym zakresie w dużej mierze został już zakończony. Polska uzyskała okresy przejściowe do ujednolicenia prawa (Wieniawski 2005: 163-170).

\section{Polskie rozwiązania konstytucyjne}

Na poziomie krajowym podstawowe znaczenie należy nadać postanowieniom Konstytucji RP (E). Poprzez art. 39 prawodawca uznał, iż nikt nie może być poddany eksperymentom naukowym, w tym medycz- 
nym, bez dobrowolnie wyrażonej zgody. Treść przytoczonego fragmentu ustawy zasadniczej stanowi powtórzenie postanowień Międzynarodowego Paktu Praw Osobistych i Politycznych. Kwestiom przeprowadzania eksperymentu medycznego nadano wysoką rangę w hierarchii praw człowieka, ponieważ zaliczono je do wolności i praw osobistych. Prawodawca konstytucyjny uznał, iż tuż za podstawowym prawem do życia, powinien się znajdować zakaz poddawania ludzi eksperymentowi naukowemu. Wśród badań naukowych przeprowadzanych na człowieku, podkreślono szczególne znaczenie eksperymentu medycznego, poprzez bezpośrednie jego wymienienie. Nie może to dziwić, ponieważ to właśnie eksperyment medyczny wydał się prawodawcy eksperymentem, który w największym stopniu może ingerować w godność człowieka. Warto zauważyć, iż prawodawca konstytucyjny wprowadzając generalny zakaz poddawania ludzi eksperymentowi medycznemu, zarazem wprowadził wyjątek, który umożliwia przeprowadzania badań naukowych. Wyjątek jest związany z dobrowolnie wyrażoną zgodą przez osobę, która ma być poddana eksperymentowi. Oznacza to, iż poprzez rozstrzygnięcia konstytucyjne prawodawca polski uznał, iż dobrowolna zgoda danej osoby, stanowi podstawę do uchylenia zakazu dokonywania konkretnego eksperymentu w jej konkretnym przypadku. Zatem dana osoba ma pełne prawo do transferu pewnej wiązki uprawnień na rzecz osoby przeprowadzającej eksperyment medyczny. W ten sposób następuje uchylenie zakazu ingerencji w prawa osoby, która wyraziła dobrowolną zgodę. W konkretnym przypadku, w ściśle oznaczonym czasie, ustają ściśle oznaczone korelatywne obowiązki ściśle oznaczonej osoby albo osób (McConnell 2000: 5-14). Warto zarazem podkreślić, iż $\mathrm{w}$ art. 39 prawodawca odwołuje się do dobrowolnie wyrażonej zgody, jednak nie wskazuje bezpośrednio czyja to ma być zgoda. Wykładnia celowościowa oraz ranga rozważanego prawa człowieka, wskazuje, iż jedyną upoważnioną osobą do wyrażenia zgody na przeprowadzenie eksperymentu medycznego powinna być osoba, na której organizmie ma być przeprowadzony eksperyment. Tylko ona jest dysponentem 
prawa, które może przekazać chwilowo na rzecz innej osoby w konkretnym szczególnym przypadku.

Dobrowolna zgoda, jako conditio sine qua non przeprowadzenia eksperymentu medycznego, umożliwia realizację wolności badań naukowych w poddawanym refleksji obszarze. Można zatem uznać, iż zastosowana konstrukcja w obszarze badań naukowych na organizmie ludzkim współgra zarazem z generalną zasadą swobody aktywności w poszerzaniu wiedzy. W myśl art. 73 polskiej ustawy zasadniczej każdemu zapewnia się wolność badań naukowych oraz ogłaszania ich wyników. Zarazem zasadne jest stanowisko, iż zakres swobody wolności naukowej odnośnie eksperymentu medycznego jest w pełni uzależniony od dobrowolnej zgody osoby, na której ma być on przeprowadzony.

Interesującym zagadnieniem jest porównanie umiejscowienia kwestii generalnego zakazu dokonywania eksperymentu medycznego oraz wolności badań naukowych. Jak zwrócono już wcześniej uwagę, kwestia zakazu eksperymentu medycznego została uregulowana wśród wolności i praw osobistych. Natomiast zagadnienie wolności badań naukowych jest zlokalizowane wśród wolności i praw ekonomicznych, socjalnych i kulturalnych. Zważywszy na podkreślaną w doktrynie różnice pomiędzy wagą i zakresem ochrony obydwu generacji praw człowieka, wypada przyjąć stanowisko, iż na tle polskiej Konstytucji, prawo do „nie bycia przedmiotem eksperymentu medycznego” bez dobrowolnej zgody w zderzeniu z prawem do badań naukowych posiada nadrzędną pozycję. Powinno to zatem być odzwierciedlone w aktach prawa niższego rzędu.

\section{Rozwiązania prawnokarne}

Zasadniczo na tle postanowień prawa karnego istnieje generalny zakaz ingerencji w organizm innej osoby. Zakaz ten jest poparty sankcjami karnymi. Jednak w pewnych przypadkach dochodzi do sytuacji, w których pomimo wypełnia znamiona typu czynu zabronionego, czyn popełniony przez człowieka nie jest społecznie niebezpieczny, a tym 
samym nie jest bezprawny. Najczęściej jest on określany w literaturze przedmiotu mianem kontratypu (Wolter 1963: 507). O kontratypie można mówić w sytuacji, w której mamy do czynienia z wystąpieniem kolizji dóbr prawnych. Jedynym odpowiednim zachowaniem jest wybór dobra, któremu nadaje się wyższe miejsce w hierarchii dóbr. Konsekwencją wyboru jest działanie nakierowane na ochronę jednego z tych dóbr kosztem drugiego dobra. W procesie wyboru dobra, któremu nadaje się priorytet, decyduje porównanie społecznej wartości i opłacalności ważonych dóbr. Proces ważenia nie oznacza, że poświęcone dobro traci wartość dobra prawnego (Zoll 1982: 110 i n.). Jednak w hierarchii zajmuje niższą pozycję. Eksperyment medyczny określany jest jako kontratyp dozwolonego ryzyka nowatorstwa. Uwzględnienie pozytywnych efektów badań naukowych zezwala na przyjęcie stanowiska, iż pewne zachowanie ludzkie, polegające na ingerencji w organizm drugiego człowieka, pomimo, iż uznawane jest generalnie za czyn zakazany, jest dopuszczalne i nie prowadzi do odpowiedzialności prawnokarnej. W ustawie z dnia 6 czerwca 1997 r. Kodeks karny (F) prawodawca określił wyłącznie odpowiedzialności karnej za przeprowadzenie eksperymentu medycznego na organizmie ludzkim. W $₫ 1$ art. 27. ustawy Kodeks karny, prawodawca uznał, iż nie popełnia przestępstwa, kto działa w celu przeprowadzenia eksperymentu poznawczego, medycznego, technicznego lub ekonomicznego, jeżeli spodziewana korzyść ma istotne znaczenie poznawcze, medyczne lub gospodarcze, a oczekiwanie jej osiągnięcia, celowość oraz sposób przeprowadzenia eksperymentu są zasadne w świetle aktualnego stanu wiedzy. Jednocześnie, w ślad za postanowieniami Konstytucji RP w $\$ 2$ art. 27 ustawy Kodeks karny, podkreślono, iż eksperyment jest niedopuszczalny bez zgody uczestnika, na którym jest przeprowadzany, należycie poinformowanego o spodziewanych korzyściach i grożących mu ujemnych skutkach oraz prawdopodobieństwie ich powstania, jak również o możliwości odstąpienia od udziału w eksperymencie na każdym jego etapie (Górski 2001: 87 i 95). 


\section{Eksperyment medyczny a zawód lekarza}

Pomimo świadomości przeprowadzania w Polsce eksperymentów medycznych, przez dłuższy okres czasu prawodawca nie decydował się na przyjęcie odpowiednich postanowień, które by odnosiły omawiane zagadnienie do uprawnień i obowiązków lekarza (Kujawa 2011: 69). W związku z tym, przez dłuższy okres czasu praktyka była oparta na Kodeksie Etyki Lekarskiej z 1991 r. Obecnie aktem wewnętrznym samorządu lekarskiego, który odwołuje się do badań naukowych jest Kodeks Etyki Lekarskiej z 2004 r. Poddawanemu refleksji zagadnieniu poświecono rozdział II. Zgodnie z jego art. 41a, lekarz przeprowadzający badania naukowe, a w szczególności eksperymenty medyczne, powinien przestrzegać norm i obowiązków wynikających z Kodeksu Etyki Lekarskiej oraz ogólnie przyjętych zasad etyki badań naukowych. Wypada zauważyć, iż wspomniane akty nie są aktami prawa powszechnie obowiązującego w Polsce.

Aktem prawa powszechnie obowiązującego, który wyznacza ramy dla eksperymentu medycznego, jest w Polsce ustawa $\mathrm{z}$ dnia 5 grudnia 1996 r. o zawodach lekarza i lekarza dentysty (D). Można powiedzieć, iż jest to podstawowa ustawa zwykła dla rozważanej tematyki ponieważ, w innych aktach dotyczących eksperymentu medycznego w przypadkach nieuregulowanych, prawodawca odsyła właśnie do ustawy z 5 grudnia 1996 r. Zarazem warto zauważyć, iż uregulowana w analizowanym akcie problematyka badań naukowych, ze względu na podstawowy przedmiot ustawy o zawodach lekarza i lekarza dentysty, ma charakter dodatkowy. Powoduje to, iż mamy do czynienia $\mathrm{z}$ wąskim spojrzeniem na eksperyment medyczny od strony określenia zasad i warunków wykonywania zawodów lekarza i lekarza dentysty. To wąskie spojrzenie skutkuje między innymi brakiem w ustawie legalnej definicji eksperymentu medycznego oraz brakiem położenia akcentu na medyczne badania naukowe. Eksperyment medyczny jest unormowany jako jeden $\mathrm{z}$ wielu obszarów aktywności lekarza. 
Zarazem wagę badań naukowych dla działań lekarza podkreślono poprzez odniesienie już na początku ustawy z 1996 r.. Zgodnie z art. 2 za wykonywanie zawodu lekarza uważa się także prowadzenie przez lekarza prac badawczych w dziedzinie nauk medycznych. Znaczenie eksperymentu medycznego wyartykułowano również poprzez poświecenie temu zagadnieniu osobnego rozdziału ustawy.

W myśl postanowień art. 22 ustawy eksperyment medyczny może być przeprowadzany, jeżeli spodziewana korzyść lecznicza lub poznawcza ma istotne znaczenie, a przewidywane osiągnięcie tej korzyści oraz celowość i sposób przeprowadzania eksperymentu są zasadne w świetle aktualnego stanu wiedzy i zgodne z zasadami etyki lekarskiej. W przywołanej jednostce redakcyjnej unormowano podstawowe przesłanki, które są punktem wyjścia przeprowadzenia eksperymentu medycznego.

Stosownie do art. 21, wśród eksperymentów medycznych przeprowadzanych na ludziach można wyróżnić eksperyment leczniczy albo eksperyment badawczy. Eksperyment leczniczy polega na wprowadzeniu przez lekarza nowych lub tylko częściowo wypróbowanych metod diagnostycznych, leczniczych lub profilaktycznych w celu osiągnięcia bezpośredniej korzyści dla zdrowia osoby leczonej. Może on być przeprowadzony, jeżeli dotychczas stosowane metody medyczne nie są skuteczne lub jeżeli ich skuteczność nie jest wystarczająca. Na uwagę zasługuje podkreślenie przez prawodawcę celu eksperymentu leczniczego, czyli bezpośrednia korzyść dla zdrowia osoby, na której organizmie dokonywana jest ingerencja. Ponadto taki rodzaj eksperymentu może być przeprowadzany tylko na osobie chorej. Odmienny charakter posiada eksperyment badawczy. Jego celem jest przede wszystkim rozszerzenie wiedzy medycznej. Może być on przeprowadzany zarówno na osobach chorych, jak i zdrowych. Przeprowadzenie eksperymentu badawczego jest dopuszczalne wówczas, gdy uczestnictwo w nim nie jest związane $\mathrm{z}$ ryzykiem albo też ryzyko jest niewielkie i nie pozostaje w dysproporcji do możliwych pozytywnych rezultatów takiego eksperymentu. W literaturze dokładnie opisano różnice pomiędzy obydwoma rodzajami eksperymentów (Wnukiewicz-Kozłowska 2004: 26 i n.). 
Prawodawca określił, iż eksperymentem medycznym ma prawo kierować wyłącznie lekarz, który posiada odpowiednio wysokie kwalifikacje.

Prawodawca polski szczególne znaczenie nadał kwestiom informowania. W myśl art. 24 osoba, która ma być poddana eksperymentowi medycznemu, powinna zostać uprzednio poinformowana o celach, sposobach i warunkach przeprowadzenia eksperymentu, spodziewanych korzyściach leczniczych lub poznawczych, ryzyku oraz o możliwości odstąpienia od udziału w eksperymencie w każdym jego stadium. Zgoda osoby na przeprowadzenie na jej organizmie eksperymentu ma charakter kwalifikowany - zasadniczo niezbędne jest oświadczenie na piśmie. Zgoda powinna być odnotowana w dokumentacji lekarskiej. Eksperyment medyczny może być przeprowadzony wyłącznie po wyrażeniu pozytywnej opinii o projekcie przez niezależną komisję bioetyczną (Rozwadowska E. et al. 2011: 77). Brak opinii w połączeniu z negatywnymi skutkami eksperymentu będzie skutkować poniesieniem odpowiedzialności karnej (Fiutak 2010: 189). Polski prawodawca szeroko również uregulował kwestie tzw. „grup wrażliwych”, czyli osób, które nie mogą spełnić podstawowego warunku przeprowadzenia eksperymentu - nie mogą udzielić świadomej lub dobrowolnej zgody, albo osoby te pozostają w pewnej roli albo występuję sytuacja, w której zachodzi przypuszczenie, iż zgoda przez te osoby wyrażona nie spełnia wymagań w zakresie zgody. Można wspomnieć o: małoletnich, osobach ubezwłasnowolnionych, pacjentach nieprzytomnych, osobach, które nie są $\mathrm{w}$ stanie $\mathrm{z}$ rozeznaniem wypowiedzieć opinii $\mathrm{w}$ sprawie swego uczestnictwa w eksperymencie, dzieciach poczętych, żołnierzach służby zasadniczej oraz osobach pozbawionych wolności, kobietach ciężarnych.

Informacja uzyskana $\mathrm{w}$ związku $\mathrm{z}$ eksperymentem medycznym może być wykorzystana do celów naukowych, bez zgody osoby poddanej temu eksperymentowi, w sposób uniemożliwiający identyfikację tej osoby. 
Warto podkreślić, iż osoba, na której organizmie jest przeprowadzany eksperyment albo inny dysponent prawa do zgody, zachowuje prawo do cofnięcia zgody. Wskazuje na to treść art. 27 analizowanej ustawy. Osoba lub inny podmiot uprawniony do udzielenia zgody na eksperyment medyczny może ją cofnąć w każdym stadium eksperymentu. W takiej sytuacji lekarz powinien eksperyment przerwać. Lekarz prowadzący eksperyment leczniczy ma obowiązek przerwać go również, jeżeli w czasie jego trwania wystąpi zagrożenie zdrowia chorego przewyższające spodziewane dla niego korzyści.

Oprócz postanowień ustawy o zawodach lekarza i lekarza dentysty, w prawie polskim znajduje się szereg szczegółowych regulacji, które dotyczą eksperymentu medycznego. Wśród nich należy wymienić chociażby postanowienia: ustawy z dnia 20 maja 2010 r. o wyrobach medycznych, ustawy z dnia 1 lipca 2005 r. o pobieraniu, przechowywaniu i przeszczepianiu komórek, tkanek i narządów, ustawy z dnia 6 września 2001 r. Prawo farmaceutyczne oraz ustawy z dnia 15 lipca 2011 r. o zawodach pielęgniarki i położnej.

\section{Zakończenie}

Dokonany przegląd wybranych postanowień prawa, od poziomu międzynarodowego, poprzez poziom europejski, a na krajowym poziomie kończąc, wskazuje, iż problematyka eksperymentu medycznego na wskroś przenika różne poziomy stanowienia prawa. Dwa elementy pojawiają się na każdym poziomie - rozwój społeczeństwa oraz bezpieczeństwo jednostek $w$ aspekcie gwarancji praw człowieka. $Z$ tego też powodu można uznać, iż medyczne badania naukowe prowadzone na organizmie człowieka stanowią odpowiedni przedmiot regulacji, aby można było zacząć budować w analizowanym obszarze koncepcję prawa globalnego. Tego typu zestawienie regulacji na różnych poziomach stanowienia prawa, które odnoszą się do globalnej problematyki wolności naukowej w zderzeniu z systemem ochrony praw człowieka, dają asumpt do przełamywania barier występujących pomiędzy systemami 
prawa. Przez wzgląd na zrównoważony rozwój człowieka, który wiąże się z globalną troską, warto patrzeć się na prawo eksperymentu medycznego jako jedną całość. Kultura prawna ulega przeobrażeniu pod wpływem wyzwania, jakim jest eksperyment medyczny. Znikają pewne bariery oraz pojawia się szereg nowych powiązań pomiędzy prawem międzynarodowym, regionalnym i krajowym.

\section{Bibliografia}

\section{Literatura}

Baker, J. R., 1978, Michael Polanyi's contributions to the cause of freedom in science, Minerva, Vol.16.

Boven T. C., 1982, Distinguishing Criteria of Human Rights (in:) K. Vasak, "The international dimensions of human rights", Paris, Vol. 1.

Czapliński W., Wyrozumska A., 2004, Prawo międzynarodowe publiczne. Zagadnienia systemowe, Warszawa.

Drozdowska U., Wojtal W., 2010., Zgoda i informowanie pacjenta, Warszawa.

Fiutak A., 2010, Prawo w medycynie, Warszawa.

Górski A., 2001, O obowiązku lekarza poinformowania pacjenta i zgodzie pacjenta na zabieg, Studia Iuridica nr 39/2001.

Herling J., 2006, Medical law and ethics, New York.

Kondrat M., 2009, Prawo farmaceutyczne komentarz, Warszawa.

Kramska M., 2011, Międzynarodowe i europejskie standardy ochrony genomu ludzkiego a preimplantacyjna diagnostyka genetyczna, Prawo i medycyna, nr 3.

Kujawa E., 2011, Eksperyment w medycynie - regulacje prawne i deontologiczne (w:) H. Jędrkiewicz (red.), „Prawo medyczne. Wybrane zagadnienia”, Warszawa.

Larsen B.U., 1976, Legal Aspects of Medical Experimentation, Scandinavian Studies in Law, Vol. 20.

Łuków P. 2007, Etyczne podstawy świadomej zgody na postępowanie medyczne $w$ Europejskiej Konwencji Bioetycznej, Prawo i medycyna, nr 4.

Łuków P., 2011, Rola światopoglądów w tworzeniu prawa medycznego, Prawo i medycyna, $\mathrm{nr} 1$.

McConnell T., 2000, Inalienable rights, New York.

President's Council on Bioethics, 2002, Human Cloning and Human Dignity: An Ethical Inquiry - Executive Summary, The [legislation] Issues in Law \& Medicine, Vol. 18. 
Rozwadowska E. i inni, 2011, Eksperyment medyczny na ludziach w świetle prawa, (w:) E. Krajewska-Kułak i inni (red.), W drodze do brzegu życia, Tom VIII, Białystok.

Safjan M., 2000, Prawo polskie a Europejska Konwencja Bioetyczna, Prawo i medycyna, nr 5.

Schott M. 2005, Medical Research on Humans: Regulation in Switzerland, the European Union, and the United States, Food and Drug Law Journal, Vol. 60.

Wachter M. A., 1997, The European convention on bioethics, Hastings Center Report, , Vol 27.

Walter M. 2004, Badania kliniczne - organizacja, nadzór, monitorowanie, Warszawa.

Wieniawski W., 2005, Dalsze zmiany w prawie farmaceutycznym Unii Europejskiej, Farmacja Polska, nr 4.

Wnukiewicz-Kozłowska A., 2004, Eksperyment medyczny na organizmie ludzkim $w$ prawie międzynarodowym i europejskim, Warszawa.

Wolter W., 1963, O kontratypach i braku społecznej szkodliwości czynu, Państwo i Prawo, nr 10.

Woltjen M., 1986, Regulation of Informed Consent to Human Experimentation, Loyola University of Chicago Law Journal, Vol. 17.

Wójcik P., 2011, Zarządzanie ryzykiem medycznym, Prawo i medycyna, nr 3.

Zoll A., 1982, Okoliczności wyłączające bezprawność czynu. Zagadnienia ogólne, Warszawa.

\section{Witryny internetowe}

(web-01) S. Kowalczyk, Granice nauki, <http://www.forumakad.pl/archiwum/2000/06/ artykuly/11-granice_nauki.htm>, dostęp: 13.07.2012.

(web-02) The Universal Declaration of Human Rights (UDHR) is a declaration adopted by the United Nations General Assembly (10 December 1948), <http://www.un.org/ en/documents/udhr/>, dostęp: 10.05.2012.

(web-03) Szerzej na temat "pseudoeksperymentów" dokonywanych przez Niemców podczas II wojny światowej, <http://www.enotes.com/medical-experimentation-reference/medical-experimentation>, dostęp: 17.06.2012.

(web-04) Konwencje o ochronie ofiar wojny, <http://www.icrc.org/ihl.nsf/CONVPRES?OpenView>, dostęp: 17.06.2012.

(web-05) Convention for the Protection of Human Rights and Dignity of the Human Being with regard to the Application of Biology and Medicine: Convention on Human Rights and Biomedicine Oviedo, 4.IV.1997, <http://conventions.coe.int/Treaty/en/ Treaties/Html/164.htm>, dostęp: 20.06.2012.

\section{Akty prawne}

(A) Konwencje o ochronie ofiar wojny, podpisane w Genewie dnia 12 sierpnia 1949 roku, (Dz.U. 1956 nr 38 poz. 171). 
(B) Konwencja Genewska o ochronie osób cywilnych podczas wojny (IV Konwencja Genewska), Genewa, 12 sierpnia 1949 r. ( Dz.U. z 1956 r., nr 38, poz. 171, załącznik)

(C) Międzynarodowy Pakt Praw Obywatelskich i Politycznych otwarty do podpisu w Nowym Jorku dnia 19 grudnia 1966 r. (Dz.U. 1977 nr 38 poz. 167, załącznik).

(D) Ustawa z dnia 5 grudnia 1996 r. o zawodach lekarza i lekarza dentysty (t. jedn. Dz.U. 2011 nr 277 poz. 1634, z późn zm.).

(E) Konstytucja Rzeczypospolitej Polskiej z dnia 2 kwietnia 1997 r. uchwalona przez Zgromadzenie Narodowe w dniu 2 kwietnia 1997 r., przyjęta przez Naród w referendum konstytucyjnym w dniu 25 maja 1997 r., podpisana przez Prezydenta Rzeczypospolitej Polskiej w dniu 16 lipca 1997 r. (Dz.U. 1997 nr 78 poz. 483, z późn. $\mathrm{zm}$.).

(F) Ustawa z dnia 6 czerwca 1997 r. - Kodeks karny (Dz.U. 1997 nr 88 poz. 553, z późn zm.)

(G) Dyrektywa 2001/20/WE Parlamentu Europejskiego i Rady z dnia 4 kwietnia 2001 r. w sprawie zbliżania przepisów ustawowych, wykonawczych i administracyjnych Państw Członkowskich, odnoszących się do wdrożenia zasady dobrej praktyki klinicznej w prowadzeniu badań klinicznych produktów leczniczych, przeznaczonych do stosowania przez człowieka, (Dz.U. UE L 121, 01.05.2001 s. 34-44).

(H) Dyrektywa 2005/28/WE Komisji z dnia 8 kwietnia 2005 r. ustalająca zasady oraz szczegółowe wytyczne dobrej praktyki klinicznej w odniesieniu do badanych produktów leczniczych przeznaczonych do stosowania u ludzi, a także wymogi zatwierdzania produkcji oraz przywozu takich produktów, (Dz.U UE L 91, 9.4.2005, s. 13-19). 